Przegląd Narodowościowy / Review of Nationalities • nr 7/2017 • World of Slavs / Świat Słowian

\title{
"Tetiček" and his concept of democracy. Analysis of the issue based on the book of Professor Marek Bankowicz entitled Demokracja według T.G. Masaryka (Democracy according to T.G. Masaryk) \\ „Tetiček" i jego koncepcja demokracji \\ Analiza zagadnienia na podstawie książki profesora Marka Bankowicza pt. Demokracja według T.G. Masaryka
}

Initials “T.G.M." are - probably - with the same ease of recognition among the Czechs, such as "JP II" among Poles. Despite a slight geographical distance between the two metropolitan cities, i.e. Warsaw and Prague, the first Czechoslovak President Tomasz Garrigue Masaryk (1850-1937) was not widely known to the Polish readers. Especially for the one who is not professionally involved in history, political science or Bohemian studies. What a shame.

Of course, it would be far simpler to say unequivocally that Tomasz G. Masaryk was not and is not a readable figure, at least for some Poles. With the literature of the father of independent Czechoslovakia, the Polish reader might have been acquainted even before 1939', when he

\footnotetext{
1 During the interwar period in the Second Polish Republic, T.G. Masaryk's works were propagated mainly through numerous translations from Czech into Polish, which were later published, among others, by the Polish-Czechoslovak Society. Among the people popularizing the heritage of Masaryk on the Vistula River are: prof. Władysław M. Kozłowski (1858-1935), Ostap Ortwin (1876-1942), Adolf Czer-
}

Inicjały „T.G.M.” są - prawdopodobnie z taką samą łatwością rozpoznawane pośród Czechów jak np. „JP II” wśród Polaków. Pomimo nieznacznej odległości geograficznej, pomiędzy dwoma miastami stołecznymi, tj. Warszawą i Pragą, osoba pierwszego prezydenta pierwszej Republiki Czechosłowackiej - Tomasza Garrigue Masaryka (1850-1937) - nie wydaje się powszechnie znana polskiemu czytelnikowi. Szczególnie temu, który zawodowo nie jest związany z nauką historii, politologii czy bohemistyki. A szkoda.

Oczywiście byłoby dalekim uproszczeniem jednoznaczne stwierdzić, że Tomasz G. Masaryk nie był i nie jest czytelną postacią, przynajmniej dla części Polaków. Z literaturą „ojca niepodległej Czechosłowacji” polski czytelnik mógł się zapoznać jeszcze przed 1939 r. ${ }^{1}$, kiedy był on - po-

1 Piśmiennictwo T.G. Masaryka w czasie dwudziestolecia międzywojennego w II RP propagowane było głównie poprzez liczne tłumaczenia z języka czeskiego na język polski, które później wydawane były m.in. przez Towarzystwo Polsko-Czechosłowackie. Do grona osób upowszechniających dziedzictwo

\footnotetext{
* Correspondence address: Instytut Bezpieczeństwa i Edukacji Obywatelskiej, Uniwersytet Pedagogiczny im. KEN w Krakowie, ul. Podchorążych 2, 30-084 Kraków, e-mail: pskorut@wp.pl.
} 
was - like Józef Piłsudski in the case of the Second Republic - admired for determination in the restoration and reconstruction of the state of the Czechs and the Slovaks. When he was also an active political actor - recognizable both on the European and American continent.

Masaryk's death in September 1937 and initiated a year later by the Munich Agreement the decline of the Czechoslovak statehood ${ }^{2}$, and then the outbreak of World War II and the communist political system imposed in Central and Eastern Europe after the end of the war, froze the process of publishing "Tetiček's" works, among others, in Poland ${ }^{3}$. This stagnation, lasting until the nineties of the twentieth century, when the wave of systemic changes, started by the autumn of 1989 people, among others, made Polish book market pluralistic.

The return of Masaryk senior on the Vistula was not automatic ${ }^{4}$. Prior to his work, as one of the tools of scientific

ny (1864-1952) or Kazimierz Kierski (1873-1944). See: T.G. Masaryk, O Bolszewiźmie, trans. A. Czerny, Warszawa 1922; idem, Słowianie po wojnie, trans. and introduction by O. Ortwin, Lwów 1924; idem, Rewolucja światowa, trans. and edit. by W.M. Kozłowski, Warszawa-Poznań-Kraków-Lwów-Stanisławów, n.d.

2 See: H. Batowski, Zdrada monachijska, Poznań, 1973.

${ }^{3}$ We should remember that at the same time behind the so called "iron curtain" T.G. Masaryk's works were popular among both scientists and popularizers of his legacy. Among this wide circle, the following should be mentioned: K. Čapek, Talks with T.G. Masaryk, New York 1953; J.H. Hajek, T.G. Masaryk Revisited. A Critical Assessment, New York 1983; E. Schmidt-Hartmann, Thomas G. Masaryk's Realism. Origins of a Czech Political Concept, München 1984; R. Szporluk, The Political Thoght of Thomas G. Masaryk, New York 1981 etc.

${ }^{4}$ In the historical memory, two Masaryks were found: Tomasz G. Masaryk (1850-1937) and his son, Jan Masaryk (1886-1948). dobnie jak Józef Piłsudski w przypadku II Rzeczypospolitej - podziwiany za determinację w przywróceniu i odbudowie bytu państwowego Czechów i Słowaków oraz aktywnym aktorem politycznym rozpoznawalnym zarówno na kontynencie europejskim, jak i amerykańskim.

Śmierć Masaryka we wrześniu 1937 r. i zapoczątkowany rok później poprzez Układ Monachijski schyłek państwowości czechosłowackiej ${ }^{2}$, a następnie wybuch II wojny światowej i narzucony po jej zakończeniu komunistyczny system polityczny w Europie środkowo-wschodniej zamroził na długie lata swobodny proces wydawniczy dzieł „Tetička”, m.in. i w Polsce $^{3}$. Owa stagnacja trwała aż do lat 90. $\mathrm{XX}$ w., kiedy to na fali przemian ustrojowych - zapoczątkowanych przez jesień ludów z 1989 r. - spluralizowany został m.in. polski rynek książkowy.

Masaryka nad Wisłą zaliczyć należy: prof. Władysława M. Kozłowskiego (1858-1935), Ostapa Ortwina (1876-1942), Adolfa Czernego (1864-1952) czy Kazimierza Kierskiego (1873-1944). Zob. T.G. Masaryk, O Bolszewiźmie, tłum. A. Czerny, Warszawa 1922; idem, Słowianie po wojnie, tłum. i wstęp O. Ortwin, Lwów 1924; idem, Rewolucja światowa, tłum. i oprac. W.M. Kozłowski, Warszawa-Poznań-Kraków-Lwów-Stanisławów [b.d.w.].

${ }_{2}$ Zob. H. Batowski, Zdrada monachijska, Poznań 1973

${ }^{3}$ Pamiętać należy, że w tym samym czasie za tzw. żelazną kurtyną prace T.G. Masaryka znajdowały zainteresowanie zarówno pośród naukowców, jak i popularyzatorów jego spuścizny. Pośród tego szerokiego grona wymienić należy m.in.: K. Čapek, Talks with T.G. Masaryk, New York 1953; J.H. Hajek, T.G. Masaryk Revisited. A Critical Assessment, New York 1983; E. Schmidt-Hartmann, Thomas G. Masaryk's Realism. Origins of a Czech Political Concept, München 1984; R. Szporluk, The Political Thought of Thomas G. Masaryk, New York 1981 etc. 
knowledge of political philosophy, the Polish reader had to wait until 1996 , for compiling a comprehensive and first since 1939 his biography ${ }^{5}$. It was only in the following years, after 1996, that the translations of works and scholarly works devoted to the analysis of Masaryk philosophical, sociological and historical works flourished ${ }^{6}$.

The present-day Polish achievements of Masaryk's works have been enriched in 2015 by the book by Marek Bankowicz "Demokracja według T.G. Masaryka" (Democracy by T.G. Masaryk), published by the Jagiellonian University Publishing House in Cracow. What is worth to notice, although it is the first reading of this author devoted entirely to Masaryk, it was preceded by numerous scientific publications on both the bohemian ${ }^{7}$ and system ${ }^{8}$ issues. They among others have significantly gave the researcher the ability to acquire a wide-angle research apparatus through which in an interesting, occupying and far-

5 See: J. Gruchała, Tomasz G. Masaryk, Wrocław 1996.

${ }^{6}$ See among others: J. Kilias, Naród a idea narodowa. Nacjonalizm T.G. Masaryka, Warszawa 1998; A. Łuszczyński, Myśl polityczno-prawna Tomasza G. Masaryka jako rodzaj mitu państwowotwórczego, Rzeszów 2013; K.Čapek, Rozmowy z T.G. Masarykiem, trans. P. Godlewski, Warszawa, 2014 etc.

7 See among others: M. Bankowicz, Tomasz G. Masaryk - apostoł demokracji, "Tygodnik Powszechny”, 29 IX 1991, No 39, pp. 4-5; idem, System władzy państwowej Czechosłowacji i Czech. Studium instytucjonalno-polityczne, Kraków 1998; idem, Zlikwidowane państwo; ze studiów nad polityka Czechosłowacji, Kraków 2003 etc.

8 See among others: idem, Demokraci i dyktatorzy: przywódcy polityczni współczesnego świata, Kraków 1993; idem, Kulisy totalitaryzmu: polityczna teoria dyktatury proletariatu, Kraków 1995; idem, Zamach stanu: studium teoretyczne, Kraków 2003; idem, Demokracja, zasady, procedury instytucje, Kraków 2006 etc.
Powrót Masaryka seniora nad Wisłę nie był automatyczny ${ }^{4}$. Zanim sięgnięto do jego prac, jako jednego z narzędzi naukowego poznania filozofii polityki, polski czytelnik musiał aż do 1996 r. czekać na opracowanie kompleksowej i pierwszej od 1939 r. jego biografii ${ }^{5}$. Dopiero w kolejnych latach - po 1996 r. - nastąpił rozkwit wobec dotychczasowego pustkowia tłumaczeń dzieł oraz opracowań naukowych poświęconych analizie masarykowskich prac filozoficzno-socjologicznych i historycznych ${ }^{6}$.

Pokaźny współcześnie, polski dorobek omówień dzieł Masaryka został wzbogacony w 2015 r. książką Marka Bankowicza pt. Demokracja według T.G. Masaryka, opublikowaną przez Wydawnictwo Uniwersytetu Jagiellońskiego w Krakowie. Co warto zauważyć, choć jest to pierwsza lektura tego autora poświęcona w pełni Masarykowi, to poprzedzona ona została jego licznymi publikacjami naukowymi, dotyczącymi zarówno problematyki bohemistycznej ${ }^{7}$, jak i zagadnieniom ustro-

${ }^{4} \mathrm{~W}$ pamięci historycznej na trwałe swoje miejsce znaleźli dwaj Masarykowie: Tomasz G. Masaryk (1850-1937) oraz jego syn, Jan Masaryk (1886-1948).

5 Zob. J. Gruchała, Tomasz G. Masaryk, Wrocław, 1996.

6 Zob. m.in.: J. Kilias, Naród a idea narodowa. Nacjonalizm T.G. Masaryka, Warszawa 1998; A. Łuszczyński, Myśl polityczno-prawna Tomasza G. Masaryka jako rodzaj mitu państwowotwórczego, Rzeszów 2013; K. Čapek, Rozmowy z T.G. Masarykiem, tłum. P. Godlewski, Warszawa 2014 etc.

Zob. m.in.: M. Bankowicz, Tomasz G. Masaryk - apostoł demokracji, „Tygodnik Powszechny”, 29 IX 1991, nr 39, s. 4-5; idem, System władzy państwowej Czechosłowacji i Czech. Studium instytucjonalno-polityczne, Kraków 1998; idem, Zlikwidowane państwo; ze studiów nad polityka Czechosłowacji, Kraków 2003 etc. 
fetched way he has analyzed the Masaryk's philosophy of democracy. This is so difficult to grasp for the researcher, because its understanding principles were scattered by "Tetiček" among many of his works, available not only in the Czech but also in English, French or German languages.

The work of Professor Bankowicz, consisting of five chapters, was preceded by an introduction. There the author, almost from the first lines, makes the reader aware (especially the less experienced), not only that the analyzed Masaryk's views are still up-to-date, but also that his person is so unique. This unconventional character of the first president of the Czechoslovak Republic was expressed in belonging to "the very exclusive group of those who were supposed to fulfill the Platonic dream of sages-rulers". This uncommonness became a contributor to Masaryk's attitude which was far-fetched and mature, and ahead of his time. He "made politics a matter of power and domination, but a question of morality and service"10. The author of this book emphasized rightly, even in the introduction, that Tomasz G. Masaryk reasoned democracy not only as one of the political systems, among others, of Europe at the time, but above all as an attitude to life. The attitude of life, which in the Masaryk times, as well as today, you must be courageous to promote. Because, as Bankowicz, following Masaryk, writes: Democracy needs leaders, not lords.

9 See: idem, Demokracja wedtug T.G. Masaryka, Kraków, 2015, p. 12.

${ }^{10}$ Ibidem. jowym $^{8}$. To one m.in. znacząco utorowały badaczowi możliwość pozyskania szerokokątnego aparatu badawczego, poprzez który w ciekawy, zajmujący i dalece trafny sposób dokonał analizy masarykowskiej filozofii demokracji, tak trudnej do ujęcia dla badacza, gdyż jej zasady rozumienia zostały rozsypane przez „Tetička” po wielu jego pracach, dostępnych nie tylko w języku czeskim, ale i angielskim, francuskim czy niemieckim.

Praca profesora Bankowicza, składająca się z pięciu rozdziałów, poprzedzona została wstępem. Autor w nim, niemal od pierwszych linijek, uświadamia czytelnikowi (szczególnie temu mniej wytrawnemu), nie tylko utrzymującą się aktualność analizowanych poglądów Masaryka, ale i niepowtarzalność jego osoby. Owa nieszablonowość postaci pierwszego prezydenta Republiki Czechosłowackiej wyrażała się w przynależeniu ,do wielce ekskluzywnego grona tych, którym dane było spełnić Platońskie marzenie o mędrcach-władcach" . Niecodzienność ta stała się przyczynkiem dla dalece oryginalnej i dojrzałej, można by powiedzieć - wyprzedzającej swoje czasy, postawy Masaryka, który „uczynił z polityki nie kwestię władzy i dominacji, lecz zagadnienie moralności i służby" ${ }^{10}$. Słusznie autor omawianej książki podkreślił, jeszcze we wstępie, że Tomasz G. Masaryk rozumował demokrację nie tylko jako jeden

8 Zob. m.in.: idem, Demokraci i dyktatorzy: przywódcy polityczni wspótczesnego świata, Kraków 1993; idem, Kulisy totalitaryzmu: polityczna teoria dyktatury proletariatu, Kraków 1995; idem, Zamach stanu: studium teoretyczne, Kraków 2003; idem, Demokracja, zasady, procedury instytucje, Kraków 2006 etc.

9 Zob. idem, Demokracja według T.G. Masaryka, Kraków 2015, s. 12.

${ }^{10}$ Ibidem. 
It would be difficult to understand this attitude of life and thus the principles of the philosophy of democracy of Tomasz G. Masaryk without, even the shortest, reaching for his biographical outline. Understanding the imminent consequence, professor Bankowicz in the first chapter of his book presented biographical sketch of T.G.M. It is worth noting that although it is an outline, it was developed on the basis of a rich and multilingual bibliographic database, referring to both Masaryk himself and his works. An additional advantage is that Bankowicz used the works of so contemporary with Masaryk as well as contemporary with today's readers. Through this procedure, reading this chapter of the book, but also others, you have a strong impression of participation in generational exchange of thought.

The cornerstone of Masaryk's research was man and his nature. These interests evolved in interdisciplinary way and became, among others, the consequence of his views on philosophy. That is why, by attempting to define Masaryk's philosophy, many scholars write explicitly about "philosophy of practice", "philosophy of human existence" or "philosophy of human work"11. It should not be surprising that, in approving these terms, professor Bankowicz titled the second chapter of his book "Democracy as humanitarianism".

Masaryk, had to be and was aware of the significance of the Great War and the year $1918^{12}$, because it "gave [not

11 Ibidem, p. 30

12 See: A. Kaczorowski, Przestrogi Masaryka, [in:] Rozmowy z Tomaszem Garriguem Masarykiem, Wrocław 2015, pp. 5-20. z systemów politycznych m.in.: ówczesnej Europy, ale przede wszystkim jako postawę życiową. Postawę życiową, którą zarówno w czasach masarykowskich, jak i dziś, trzeba mieć odwagę promować, gdyż jak pisze Bankowicz za Masarykiem: „Demokracja potrzebuje przywódców, a nie panów".

Trudno byłoby zrozumieć ową postawę życiową, a tym samym zasady filozofii demokracji Tomasza G. Masaryka, bez, choćby najkrótszego, sięgnięcia po jego zarys biograficzny. Rozumiejąc grożące następstwo, profesor Bankowicz w pierwszym rozdziale swojej książki przedstawił szkic biograficzny T.G.M. Warto zaznaczyć, że choć jest to zarys, to został on oparty na bogatej i wielojęzycznej bazie bibliograficznej, odnoszącej się zarówno do samego Masaryka, jak i jego dzieł. Dodatkowym atutem jest sięgnięcie przez Bankowicza do prac zarówno współczesnych Masarykowi, jak i współczesnych dzisiejszym czytelnikom. Poprzez ten zabieg, czytając ów rozdział książki - ale i pozostałe też - odnosi się silne wrażenie współuczestnictwa w pokoleniowej wymianie myśli.

Kamieniem węgielnym badań naukowych Masaryka był człowiek i jego natura. Zainteresowania te ewoluowały interdyscyplinarnie i stały się m.in. następstwem głoszonych przez niego poglądów z zakresu filozofii. To dlatego podejmując próbę zdefiniowania masarykowskiej filozofii, wielu badaczy pisze wprost o "filozofii praktyki”, „filozofii ludzkiej egzystencji” czy „filozofii ludzkiego dzieła” ${ }^{11}$. Nie należy się zatem dziwić, że wychodząc naprzeciw tym określeniom - aprobując je, profesor

11 Ibidem, s. 30. 
only - added by P.S.] new political order ${ }^{13}$ but above all in Europe intensified democracy"14. Democracy, which - noted Bankowicz - was for T.G.M. something more than a political concept. It was also a way of behaving or even a view of life ${ }^{15}$. The author of the book strengthened such an interpretation among others with the reflections of the Dutch researcher Anton van den Beld, concerning both the multifaceted understanding of Masaryk's democracy and the non-standardization of the semantic perceiving of its meaning ${ }^{16}$.

According to the Cracow researcher, the concept of Masaryk's philosophy of democracy was based on three pillars: a) humanism, b) moral principles derived from Christian teaching, and c) traditions of enlightenment ${ }^{17}$. This unique, never-beforeseen form of democracy, far removed from the liberal version promoted successfully in Europe during the interwar period of the twentieth century, was a coherent concept in the mindset of the Czechoslovak thinker. It was based, among others, on the concept of harmony and mutual respect between the rulers and the governed.

Professor Bankowicz, in the next part of his chapter, noted and described precisely and curiously the difference between Masaryk's humanism and humanitarianism. Although both of these concepts found active use in the dream of democracy

\footnotetext{
13 See: T.G. Masaryk, Rewolucja światowa, p. 577.

14 Ibidem, p. 581.

15 M.Bankowicz,Demokracjawedług...,pp. 39, 43.

${ }_{16}$ Ibidem, pp. 39-40.

17 Ibidem, p. 38.
}

Bankowicz zatytułował drugi rozdział swojej książki Demokracja jako humanitaryzm.

Masaryk musiał mieć i miał świadomość doniosłości Wielkiej Wojny oraz roku $1918^{12}$, to bowiem "nadało [nie tylko przyp. P.S.] nowy porządek polityczny ${ }^{13}$, ale przede wszystkim w Europie spotęgowało demokrację"14. Demokrację, która co zauważył Bankowicz - była dla T.G.M. czymś więcej niż pojęciem politycznym - także sposobem zachowania czy nawet poglądem na życie ${ }^{15}$. Taką interpretację autor książki wzmocnił m.in. przemyśleniami holenderskiego badacza Antona van den Belda, dotyczącymi zarówno wieloaspektowości rozumienia demokracji u Masaryka, jak i podkreślającymi niestandardowość w semantycznym postrzeganiu jej znaczenia ${ }^{16}$.

Według krakowskiego badacza, koncepcja filozofii demokracji Masaryka oparta była na trzech filarach: a) humanizmie, b) zasadach moralnych wywiedzionych z nauki chrześcijańskiej oraz c) tradycji oświecenia ${ }^{17}$. Ta niespotykana nigdzie indziej, niecodzienna postać demokracji - dalece różniąca się od wersji liberalnej, promowanej z powodzeniem w Europie w okresie dwudziestolecia międzywojennego w XX w. - w zamyśle czechosłowackiego myśliciela była spójną koncepcją. Opierała się ona m.in. na koncepcji harmonii oraz wzajemnym po-

12 Zob. A. Kaczorowski, Przestrogi Masaryka, [w:] Rozmowy z Tomaszem Garriguem Masarykiem, Wrocław 2015, s. 5-20.

13 Zob. T.G. Masaryk, Rewolucja światowa, s. 577.

14 Ibidem, s. 581.

15 M. Bankowicz, Demokracja według..., s. 39, 43.

16 Ibidem, s. 39-40.

17 Ibidem, s. 38. 
at T.G.M ${ }^{18}$, they were not equivalent to one another. Humanitarianism, writes Bankowicz, is not immanent with haumanism, though it is not contradictory ${ }^{19}$. Humanism should be, in the view of the author of analysis, perceived as another stage in the development of the Renaissance approach to humanitarianism ${ }^{20}$. What is significant, both these issues have a common scope which is the love of neighbor.

Far right and helpful for the reader, in understanding the concept of T.G.M., is a continuation of thought, analysis of differences and real meaning, influence on democracy: humanism and humanitarianism. It is worth to speak at this moment to the voice of the bohemian Cracow, who readily makes sense.

While humanism is the love of one's neighbor in the individual aspect, humanitarianism brings this love to public reality, becoming the moral basis of modern democratic politics. In other words, humanism defines interpersonal relationships while humanitarianism regulates social and political relations ${ }^{21}$.

The "jewel in the crown" of thedescription of the role of humanitarianism in Masaryk's theoretical concept of democracy can be, considered by Professor Bankowicz, the quotation from "Tetiček". It is the intellectual core of Masaryk's vision of democracy as well as the parabolic reference to the adequacy of the title of the analyzed chapter.

\footnotetext{
18 Ibidem, p. 53.

19 Ibidem, p. 32

20 Ibidem.

${ }^{21}$ Ibidem, pp. 32-33.
}

szanowaniu pomiędzy rządzącymi a rządzonymi.

Celnie i ciekawie profesor Bankowicz w kolejnej części rozdziału swojej pracy zauważył i opisał różnicę pomiędzy masarykowskim humanizmem a humanitaryzmem. Choć oba te pojęcia znalazły aktywne zastosowanie w marzeniu o demokracji u T.G.M. ${ }^{18}$, to jednak nie były one równoważne względem siebie. Humanitaryzm - pisze Bankowicz - nie jest immanentny $z$ haumanizmem, choć nie jest też mu sprzeczny ${ }^{19}$. Humanizm należy - w ocenie autora analizy - postrzegać jako „kolejną fazę rozwojową renesansowego" ujęcia humanitaryzmu ${ }^{20}$. Co jest znamienne, oba te zagadnienia mają wspólny zakres - miłość bliźniego.

Dalece zasadna i pomocna dla czytelnika - w zrozumieniu koncepcji T.G.M. jest kontynuacja myśli, analizy dotyczącej różnic i realnego znaczenia, wpływu na demokrację: humanizmu i humanitaryzmu. Warto w tym momencie oddać głos krakowskiemu bohemiście, który czytelnie ujmuje ten sens.

O ile humanizm oznacza miłość bliźniego $\mathrm{w}$ aspekcie indywidualnym, o tyle humanitaryzm przenosi tę miłość do rzeczywistości publicznej, stając się moralną podstawą nowoczesnej polityki demokratycznej. Mówiąc inaczej - humanizm określa relacje międzyludzkie, podczas gdy humanitaryzm reguluje stosunki społeczne i polityczne ${ }^{21}$.

Za zwieńczenie opisu roli humanitaryzmu w teoretycznej koncepcji demokracji u Masaryka można uznać uwzględniony

\footnotetext{
8 Ibidem, s. 53.

19 Ibidem, s. 32.

20 Ibidem.

${ }^{21}$ Ibidem, s. 32-33.
} 
If humanitarianism is the goal of all ideas (of democracy as well - added by P.S.), then it must also be the goal of all our efforts; humanitarianism can only be attained by means of humanitarian means, and therefore of enlightened mind and heart ${ }^{22}$.

It is worthwhile, just to complement the subject, to quote yet elaborated by the Bankowicz a supplement of the above thought. The Cracow researcher noted that in order to fulfill Masaryk's expectations for humanism in the process of democratization, a special role was assigned to work. Work, or rather a process of education, consciously directed at the dissemination of knowledge, education among the Czechoslovak society. Because it was the author of the analyzed study, gave the punchline using the words of T.G.M.: "democracy requires the wise and bright citizens who make up her rock"23.

The unrelenting consciousness, which should accompany the reader constantly while reading Marek Bankowicz, is that Tomasz Masaryk was not only a politician, but equally important a philosopher. This virtue, no doubt, was the dominant feature that gave his speeches a special (added) value. The way in which this kind of thinking is perceived will make it easier for the reader to understand the content of the third chapter of the book, "Unpolitical Politics".

On the departure of politics from morality and ethics, both in the Masaryk era and at the turn of the second decade of the

22 Ibidem, p. 33

23 Ibidem. przez profesora Bankowicza cytat z dzieł „Tetička”. Jest on zarówno intelektualnym rdzeniem sensu masarykowskiej wizji demokracji, jak i parabolicznym odniesieniem do adekwatności tytułu omawianego rozdziału.

Jeśli humanitaryzm jest celem wszystkich idei [też i demokracji - przyp. P.S.], zatem musi być również celem wszystkich naszych wysiłków; humanitaryzm może być osiągnięty tylko za pomocą środków humanitarnych, a więc światłego umysłu i gorącego serca ${ }^{22}$.

Warto, jedynie dla dopełnienia tematu, przytoczyć jeszcze opracowane przez Bankowicza uzupełnienie powyższej myśli. Krakowski badacz zauważył, że dla spełnienia masarykowskich oczekiwań wobec humanizmu w procesie demokratyzacji szczególną rolę przypisano pracy. Pracy, a właściwie procesowi edukowania, świadomie ukierunkowanemu na rozpowszechnianie wiedzy, oświaty pośród społeczeństwa czechosłowackiego. Bo jak to zostało przez autora omawianej analizy spuentowane słowami T.G.M.: „Demokracja wymaga mądrych i światłych obywateli, którzy stanowią jej opokę"23.

Niezatracalną myślą, która winna stale towarzyszyć czytelnikowi podczas lektury Marka Bankowicza, jest ta, że Tomasz Masaryk był nie tylko politykiem, ale co równie istotne - filozofem. Owa cnota bez wątpienia była dominantem, która nadawała jego wypowiedziom szczególną (dodaną) wartość. Przyswojenie takiego sposobu myślenia znacząco ułatwi odbiorcy zrozumienie treści trzeciego rozdzia-

\footnotetext{
22 Ibidem, s. 33

23 Ibidem.
} 
21 st century, all moralists reported and report in alarming tone. This, unfortunately, frequent limitation of politicians, and politics as well, has become the subject of attention, among others, of the first president of Czechoslovakia.

We must admit that the starting point for T.M.G. in the above topic was not agitation before the very phenomenon in the strict sense, but the continuation, or rather the evolution of the philosophy of democracy. The Democracy, which was in Masaryk's eyes, a synonym of the new style of politics, and thus the denial of the theocratic policy that had prevailed in Europe until 1918. Democracy, whose pillars, as Professor Bankowicz points out, were "at the heir of Plato's vision", science and morality. The consequence, therefore, was that, in the logical and rational world of Masaryk, the politics like medicine "would take care of the health of society" and, therefore, the health of the state ${ }^{24}$. Hence, the policy was to be derived, to be consistent with ethical and moral principles. It was supposed to deny the traditional way of perceiving it, to stop being a tool of practical or clever action. The policy was to become an art of administration. Politics was supposed to be "non-political".

Of course, the naivete being almost utopia would be to believe that such a simple scheme would not only abolish

${ }^{24}$ Ibidem, p. 65. łu książki, zatytułowanego Niepolityczna polityka.

O odchodzeniu polityki od moralności i etyki, zarówno w czasach Masaryka, jak i u progu drugiej dekady XXI w. - w alarmującym tonie donosili i donoszą wszelcy moraliści. Ta - niestety - częsta ułomność polityków, a i polityki, stała się przedmiotem uwagi m.in. i pierwszego prezydenta Czechosłowacji.

Przyznać trzeba, że punktem wyjścia dla T.M.G. w powyższym temacie nie było wzburzenie przed samym zjawiskiem sensu stricto, ale kontynuacja, a raczej ewolucja filozofii demokracji. Demokracji, która była - w masarykowskich oczach - synonimem nowego stylu uprawiania polityki, a tym samym zaprzeczeniem dla rozpowszechnionej w Europie do 1918 r. polityki teokratycznej. Demokracji, której filarami - jak słusznie zauważa profesor Bankowicz - były u „dziedzica platońskiej wizji” nauka i moralność. Konsekwencję zatem stanowiło to - tym bardziej w logiczno-racjonalnym świecie Masaryka - by polityka na wzór medycyny „dbała o zdrowie społeczeństwa”, a zatem i o zdrowie państwa ${ }^{24}$. Dlatego też polityka miała wywodzić się, być spójna z zasadami etycznymi, moralnymi. Miała być zaprzeczeniem tradycyjnego sposobu jej postrzegania, miała przestać być narzędziem działań praktycznych czy sprytnych. Polityka miała stać się sztuką administrowania. Polityka miała być „niepolityczna”.

Oczywiście naiwnością graniczącą z utopią byłoby sądzić, że tak prosty sche-

${ }^{24}$ Ibidem, s. 65. 
the alleged deficiency of politics, or the existing framework of its perception, but also promote its new face. The author of the study rightly suggested in the chapter that Masaryk outlined this issue in a much deeper and more thoughtful way.

"Tetiček" argued that the consequence of strong support for democracy by science and morality will be the influence of its entity - the citizens on the high authority of the governing. Because, as Bankowicz quoted Masaryk, "people want to be ruled by arguments, and not [by - added by P.S.] - arbitrary resolutions" ${ }^{\prime 25}$. The thought of "the father of the Czechoslovak state" went on consistently. He argued what was rightly pointed out by the author of the analysis that the consequence of education of the entity of democracy is "the process of shaping citizens and creating various forms of social life"26. And from this way of thinking, in the case of T.G.M., it was just a step to declare that politics is a kind of art. The most advanced art, because it has, according to Masaryk, "the root of poetry; there is as much poetry as creation in it"27.

The concept of "non-political politics" was not dead in the political practice of the Czechoslovak thinker. Bankowicz, on subsequent pages of this chapter, cited, among others, words spoken by Masaryk at one of his political congresses: "My program is short and clear: Do not be afraid, do not lie

\footnotetext{
${ }^{25}$ Ibidem

${ }^{26}$ Ibidem, p. 66

27 Ibidem.
}

mat mógłby nie tylko znieść zarzucaną ułomność polityki czy dotychczasowe ramy jej postrzegania, ale i wypromować nowe jej oblicze. Autor opracowania słusznie zasugerował w treści rozdziału, że Masaryk nakreślił to zagadnienie znacznie dogłębniej, w bardziej przemyślany sposób.

„Tetiček” dowodził, że konsekwencją silnego wsparcia demokracji przez m.in. naukę i moralność będzie oddziaływanie jej podmiotu - obywateli - na wysoki autorytet rządzących, gdyż, jak zacytował Bankowicz za Masarykiem, „ludzie chcą być rządzeni przez argumenty, a nie [przez przyp. P.S.] - arbitralne rozstrzygnięcia"25. Myśl „ojca czechosłowackiego państwa” szła konsekwentnie dalej. Argumentował on, co słusznie zaznaczał autor analizy, że następstwem edukacji podmiotu demokracji jest „proces kształtowania obywateli oraz tworzenie rozmaitych form życia społecznego"26 . A z tego sposobu myślenia, w przypadku T.G.M., był już tylko krok do ogłoszenia, że polityka jest rodzajem sztuki. Sztuki najwznioślejszej, gdyż posiada ona - zdaniem Masaryka - „pierwiastek poezji; ma w sobie tyle poezji, ile jest $\mathrm{w}$ niej tworzenia"'27.

Koncepcja "niepolitycznej polityki” nie była martwa w praktyce politycznej czechosłowackiego myśliciela. Bankowicz, na kolejnych kartach omawianego rozdziału, przywołał m.in. słowa wypowiedziane przez Masaryka na jednym ze swoich kongresów politycznych: „Mój program jest krótki i jasny: Nie bać się, nie kłamać i nie

\footnotetext{
25 Ibidem.

${ }^{26}$ Ibidem, s. 66

27 Ibidem.
} 
or steal! To practice a rational and honest policy, to tell the nation always the truth"28.

The complementation of the chapter, equally curious and surprising, proving that Masaryk's heritage has not been wasted, is a nearly ten-page, condensed description of the use of the concept of "non-political politics" by his later successors at the turn of the twentieth century, such as Vaclav Havel, a writer, thinker, politician ${ }^{29}$.

"Democracy is nowhere else consistently realized; all democracies are so far only an attempt at democracy" - Masaryk wrote in one of the most important publications, The World revolution ${ }^{30}$. This crude and at the same time a pertinent statement, as unfortunately revealed the history of the years 1938-1990, became indirectly the background for the fourth chapter of the book by Marek Bankowicz entitled Titanism - the enemy of democracy.

Masaryk had to be aware that not all participants in political life in reborn Czechoslovakia, and also outside it, understand what democracy is. Thereby, not every one of its entities knew or understood what threats both to the existence of democracy and to the development of non-political politics were, which ones arose and what they might be, especially in the 20th century. Therefore, in his critical philosophy of politics, T.M.G. made

28 Ibidem, p. 69

${ }^{29}$ Ibidem, pp. 80-90.

30 See: T.G. Masaryk, Rewolucja światowa, pp. $612-613$ kraść! Uprawiać politykę rozumną i uczciwą, mówić narodowi zawsze prawdę"28.

Dopełnieniem rozdziału, równie ciekawym i zaskakującym - bo udawadniającym, że dziedzictwo Masaryka nie zostało zaprzepaszczone - jest blisko dziesięciostronicowy, skondensowany opis wykorzystania koncepcji „niepolitycznej polityki” przez jego późniejszych następców u progu XX w., jak choćby przez Vaclava Havla pisarza, myśliciela, polityka ${ }^{29}$.

„Demokracja nigdzie nie jest jeszcze konsekwentnie urzeczywistniona; wszystkie państwa demokratyczne są dotąd tylko próbą demokracji” - napisał Masaryk w swojej jednej z ważniejszych publikacji pt. Rewolucja światowa ${ }^{30}$. To surowe i zarazem celne stwierdzenie - jak niestety ukazała historia z lat 1938-1990 - stało się pośrednio tłem dla czwartego rozdziału książki Marka Bankowicza, zatytułowanego Tytanizm - wróg demokracji.

Masaryk musiał mieć świadomość, że nie wszyscy uczestnicy życia politycznego w odrodzonej Czechosłowacji, a i poza nią również, rozumieją, czym jest demokracja. Tym samym nie każdy jej podmiot wiedział czy rozumiał, jakie są, jakie powstają i jakie mogą być - szczególnie w XX w. zagrożenia zarówno dla egzystencji demokracji, jak i dla rozwoju „niepolitycznej polityki”. Dlatego w swojej krytycznej filozofii polityki T.M.G. zawarł liczne przestrogi. Oczywiście, byłoby błędem sugerowanie, że stworzył on jakiś rejestr, szczegółowy katalog czy testamentowy indeks zagrożeń,

28 Ibidem, s. 69.

29 Ibidem, s. 80-90.

30 Zob. T.G. Masaryk, Rewolucja światowa, s. 612-613. 
many warnings. Of course, it would be a mistake to suggest that he created a registry, a detailed catalogue or a testamentary threat index that the citizens of "the Czechoslovak Republic" ${ }^{31}$ would follow after his departure. Professor Bankowicz have managed to develop and, with the preservation of Masaryk's arguments, present in an interesting way, these guidelines, scattered among many of his works.

Based on the analysis of the works of "Tetiček", the Cracovian Bohemian researcher listed seven threats to his thendemocracy, which in the three decades of the twentieth century were not only intellectually stimulating to the minds of the people, but often the content of the rebellion of the plebeians. Among the enemies of democracy, as Bankowicz puts it, according to Masaryk were: titanism as a symptom of human megalomania; liberalism as a denial of equality, brotherhood and community $^{32}$; nationalism ${ }^{33}$, as an example of an idea far removed from humanity, fascism - as an example of a return to barbarism, violence against the ideas of humanitarianism, and unrestrained pursuit of power ${ }^{34}$; anarchism, as a twisted form of pursuit of freedom even at the price of the existence

${ }^{31}$ In the first years of his political emigration, Masaryk, both in his letters and official speeches, talked about the need to create a new state of Czechs and Slovaks, about the Commonwealth, and called himself the President of the Commonwealth. See: T.G. Masaryk, Rewolucja światowa, p. 661.

${ }^{32}$ M. Bankowicz, op. cit., pp. 109-110.

${ }_{33}$ T.G. Masaryk distinguished two types of nationalism:" positive and negative. See: T.G. Masaryk, Rewolucja światowa, p. 651

${ }_{34}$ M. Bankowicz, op. cit., p. 117. którym obywatele „Rzeczypospolitej Czechosłowackiej” ${ }^{31}$ mieli się kierować po jego odejściu. Owe rozsypane po wielu jego pracach wskazówki udało się opracować i z zachowaniem masarykowskiej argumentacji przedstawić w dalece ciekawy sposób profesorowi Bankowiczowi.

Na podstawie analizy dzieł „Tetička”, krakowski bohemista wyszczególnił aż siedem zagrożeń dla ówczesnej mu demokracji, które w trzech dziesięcioleciach XX w. były dla niektórych nie tylko intelektualną podnietą umysłu, ale i często treścią buntu plebejuszy. Do grona owych wrogów demokracji - jak to ujmuje Bankowicz - zaliczał Masaryk: tytanizm, jako objaw megalomanii człowieka; liberalizm, jako zaprzeczenie równości, braterstwa i wspólnotowości ${ }^{32}$; nacjonalizm ${ }^{33}$, jako przykład idei odległej od humanitaryzmu, faszyzm - jako przykład powrotu do barbarzyństwa, gwałtu nad ideami humanitaryzmu i niepohamowana dążność do władzy $^{34}$; anarchizm, jako wykrzywioną formę dążenia do wolności nawet za cenę istnienia państwa ${ }^{35} \mathrm{czy}$ rewolucje - jako przykład ślepego losu na loterii lub preludium dla dyktatury, absolutyzmu ${ }^{36}$.

$31 \mathrm{~W}$ pierwszych latach swojej emigracji politycznej Masaryk zarówno w pismach, jak i w oficjalnych wypowiedziach mówił zarówno o potrzebie utworzenia nowego państwa Czechów i Słowaków, o Rzeczypospolitej, jak i sam określał się prezydentem Rzeczypospolitej. Zob. T.G. Masaryk, Rewolucja światowa, s. 661 .

${ }_{32}$ M. Bankowicz, op. cit., s. 109-110.

${ }_{33}$ T.G. Masaryk rozróżniał dwa rodzaje nacjonalizmów: pozytywny i negacyjny. Zob. T.G. Masaryk, Rewolucja światowa, s. 651.

${ }^{34}$ M. Bankowicz, op. cit., s. 117.

35 Ibidem, s. 111.

${ }^{36}$ Ibidem, s. 101. 
of the state $\mathrm{e}^{35}$ or revolutions - as an example of blind lottery or prelude to dictatorship, absolutism $^{36}$.

The briefly presented list was additionally "enriched" by the author of the book by two more people who, in the critical political writing of Masaryk, took a significant place. Not only because they represented a new political trend - communism, but for both, according to T.G.M., dismissed the rights of individuals in the name of the working masses.

Karl Marx for Masaryk was an example, on the one hand, of the propagator of the new content of the socio-political program, which was defined by Czechoslovak politician as the "crux of our knowledge, consciousness, conscience" ${ }^{\prime \prime}$. On the other hand, he was the addressee of his critical political assessment. Among the numerous allegations directed against him, professor Bankowicz rightly pointed out in his work, among other ${ }^{38}$, for the lack of Masaryk's understanding of the unnecessary co "Tetiček's" negation of Marx's philosophy was due to defense of humanitarian principles as well as to frail shape of democracy in the first decades of the last century of the twentieth century.

For a better contrast between the two thinkers, a Cracow researcher, among others, on the example of historical materialism, showed how polarized the two philosophers were in relation to each other. Bankowicz, in Masaryk's words, described:

\footnotetext{
35 Ibidem, p. 111

36 Ibidem, p. 101.

37 Ibidem, p. 93

38 Ibidem, p. 94
}

Zaprezentowana pokrótce lista została dodatkowo „wzbogacona” przez autora książki o jeszcze dwie osoby, które w krytycznym pisarstwie politycznym Masaryka zajęły znaczące miejsce. Nie tylko dlatego, że reprezentowały nowy nurt polityczny komunizm, ale dlatego, że obaj - zdaniem T.G.M. - odrzucali lekceważąco prawa jednostki w imię mas pracujących.

Karol Marks dla Masaryka był przykładem, $\mathrm{z}$ jednej strony, propagatora nowej treści programu społeczno-politycznego, która została określona przez czechosłowackiego polityka jako „crux naszej wiedzy, świadomości, sumienia" ${ }^{37}$. Z drugiej strony, był adresatem jego krytycznej oceny politycznej. Pośród licznych zarzutów kierowanych doń profesor Bankowicz słusznie zwrócił uwagę w swojej pracy m.in. na brak masarykowskiego zrozumienia wobec niepotrzebnego konstruowania „abstrakcyjnego systemu myślowego", którego los wydaje się przesądzony ${ }^{38}$. Oczywiście, owa negacja „Tetička” dla filozofii Marksa wynikała zarówno z obrony zasad humanitaryzmu, jak i wątłej w pierwszych dekadach ostatniego stulecia XX w. postawy demokracji.

Dla wyraźniejszego skontrastowania obu myślicieli, krakowski badacz, m.in. na przykładzie materializmu historycznego, ukazał, jak biegunowo obaj filozofowie usadowieni byli względem siebie. Bankowicz, słowami Masaryka, opisywał: „[materializm historyczny - przyp. P.S.] to złowróżbna idea klasowości, zakładająca bezwzględną i ostrą walkę antagonistycznych klas w ramach jednego narodu czy

\footnotetext{
37 Ibidem, s. 93
}

38 Ibidem, s. 94. 
"[historical materialism - added by P.S.] is an ominous idea of classes, assuming the absolute and fierce struggle of antagonistic classes within one nation or society, which in social and political life refers to instincts instead of reason"39.

If, among Marx and Engels' theories, Masaryk was able to find an understanding of the problems raised, especially in the context of the need to improve the economic and social fate of workers, in the case of Bolshevism and its creator, Vladimir Ilich Lenin, he was not.

Professor Bankowicz sees strong criticism of Leninism in Masaryk's writings not only in his excellent knowledge of tsarist Russia in 1910, as well as in the revolutionary Russia of 1917, when he was there during the formation of the Czechoslovak Legion but also careful study of Wlodzimierz Ilicz' works. Masaryk, in Bankowicz's opinion, directly attacked Lenin's idea for derogation, for deforming Marxist 'deas. What was an example of a departure in the wrong direction ${ }^{40}$.

But Masaryk's criticism of Lenin was more than that. Marek Bankowicz, rightly demonstrating the strongly negative view of the Czech thinker on Bolshevism and its leader, reached for the most important allegation: "the poverty of intellectual Leninism and its fascination with power and extreme anti-democratization" ${ }^{\prime 4}$. The consequence of what the author of the study reported was that in 1919 Lenin called

39 Ibidem, p. 98

40 Ibidem, p. 103.

${ }^{41}$ Ibidem, p. 104. społeczeństwa, która w życiu społecznym i politycznym zamiast do rozumu odwołuje się do instynktów"39.

Jeżeli pośród teorii Marksa i Engelsa Masaryk potrafił odnaleźć zrozumienie dla podnoszonych problemów, szczególnie $\mathrm{w}$ temacie potrzeby poprawy losu ekonomiczno-społecznego robotników, to w przypadku bolszewizmu i jego twórcy - Włodzimierza Ilicza Lenina - już nie.

Silny krytycyzm wobec leninizmu w pismach Masaryka profesor Bankowicz upatruje nie tylko w jego doskonałym znawstwie Rosji carskiej, w której był w 1910 r., i Rosji rewolucyjnej z 1917 r., kiedy przebywał tam w okresie tworzenia się legionu czechosłowackiego, ale i starannym przestudiowaniu dzieł Włodzimierza Ilicza. Masaryk, w ocenie Bankowicza, wprost atakował myśl Lenina za odstępstwo, za zdeformowanie idei marksistowskich, co było przykładem odejścia w złym kierunku ${ }^{40}$.

Jednak krytyka masarykowska Lenina nie poprzestawała tylko na tym. Marek Bankowicz, słusznie ukazując zdecydowanie negatywne stanowisko czeskiego myśliciela wobec bolszewizmu i jego przywódcy, sięgnął po najważniejszy zarzut: „ubóstwa intelektualnego leninizmu i jego fascynację władzą, a także skrajny antydemokratyzm" ${ }^{41}$. Konsekwencją tego, o czym i autor opracowania informuje, było uznanie przez Lenina w 1919 r. Masaryka za „najpoważniejszego przeciwnika ideologicznego w Europie" ${ }^{\text {"2 }}$.

\footnotetext{
39 Ibidem, s. 98.

${ }^{40}$ Ibidem, s. 103.

${ }^{41}$ Ibidem, s. 104

42 Ibidem.
} 
Masaryk "the most serious ideological opponent in Europe"42.

Compared to Plato, Masaryk was able to achieve more. In 1918, at the age of sixty-eight, he was unanimously elected president of the Czechoslovak Republic. He held the office for seventeen consecutive years, while the constitution adopted by the Czechoslovak National Assembly on 29 February 1920, provided for only one possibility of extending the term of the office. Hence, Masaryk was able to achieve more than Plato, because he could initiate the ideas he just postulated in the social and political reality of his nation.

Following this direction of reasoning, professor Bankowicz undertook, in the last chapter of the book, a very interesting task. Namely through careful analysis, among others, of the then Czechoslovak constitution and selected legislative acts of 1920-1937 of the First Czechoslovak Republic, he elaborated an extremely interesting and occupying text on "Masarykizm of Masaryk's republic".

The sketched description in Bankowicz's analysis not only shows, for example, Masaryk's fears about sensibility or coherence with the principles of democracy, for example holding the presidency (or perhaps some form of directorate ${ }^{43}$ ), but also the degree of "soaking" with Masaryk by the Czechoslovak society. This description, interestingly, is rich not only in the victories gained during Masaryk's life, but also his lapses, such as the break of the 1918

\footnotetext{
${ }^{42}$ Ibidem

${ }^{43}$ Ibidem, p. 122.
}

W porównaniu z Platonem, Masarykowi dane było więcej. W 1918 r., w wieku 68 lat został jednogłośnie obrany prezydentem Republiki Czechosłowackiej. Urząd ten sprawował przez 17 kolejnych lat, podczas gdy przyjęta przez czechosłowackie Zgromadzenie Narodowe 29 lutego $1920 \mathrm{r}$. konstytucja przewidywała tylko jednokrotną możliwość przedłużenia kadencji na tym urzędzie. Masarykowi zatem było dane więcej niż Platonowi, gdyż mógł on inicjować postulowane przez siebie koncepcje w rzeczywistości społecznej i politycznej swojego narodu.

Idąc tym kierunkiem rozumowania, profesor Bankowicz podjął się - w ostatnim rozdziale książki - bardzo ciekawego zadania. A mianowicie poprzez wnikliwą analizę m.in. ówczesnej konstytucji czechosłowackiej oraz wybranych aktów prawnych z lat 1920-1937 Pierwszej Republiki Czechosłowackiej opracował niezwykle ciekawy i zajmujący tekst dotyczący „Masarykizmu republiki Masaryka”.

Naszkicowany opis w analizie Bankowicza przedstawia nie tylko np. pewne obawy Masaryka nad sensownością czy spójnością z zasadami demokracji np. piastowanie urzędu prezydenckiego (a może np. jakaś forma dyrektoriatu ${ }^{43}$ ), ale i stopniem "przesiąknięcia” społeczeństwa nadwełtawskiego Masarykiem. Ów opis, co ciekawe, jest bogaty nie tylko w zwycięstwa odniesione jeszcze za życia Masaryka, ale i jego potknięcia, jak np.: zerwanie umowy pittsburskiej z 1918 r. czy promowanie narodowościowej koncepcji czechosłowakizmu.

${ }^{43}$ Ibidem, s. 122. 
Pittsburg Agreement or the promotion of the national concept of Czechoslovakism.

An additional, equally important achievement of this chapter is to make the reader (especially Polish) aware that even after 70 years since Masaryk's death there is a strong attachment and appeal of Czech society to the first president of Czechoslovakia. The personification of this was Vaclav Havel, who died in 2011. Was, for example, the adoption by the Czechoslovak Republic in 1990 and then adopting in 1993 by the Czech Republic the Tomás Masaryk Order, given for the achievements "in developing democracy and human rights"

Another example of the modern revival of Masaryk's political thought is the great interest in his philosophy by European, but not only, scholars, researchers of the democratic system and the role of the state in this regime.

Professor Marek Bankowicz's book, undoubtedly, is a position that not only filled the gap in world scientific literature on the analysis of the political thought of Tomasz Garrigue Masaryk, but also the elaboration which, with its content, pleasant style of writing, brings this person closer. It is also a comparative scientific work, based not only on the writings of T.G.M., but also on the multi-lingual writ-

${ }^{44}$ See: Stanovy, www.hrad.cz/cs/ceska-republika/statni-vyznamenani/ceska-a-slovenska-federa tivni-republika/rad-t.-g.-masaryka/stanovy [access on: 10.01.2017].
Dodatkowym, równie ważnym osiągnięciem opracowanego rozdziału jest uzmysłowienie czytelnikowi (szczególnie temu polskiemu), że nawet po 70 latach od śmierci Masaryka istnieje współcześnie silne przywiązanie i odwoływanie się społeczeństwa czeskiego do pierwszego prezydenta Republiki Czechosłowacji. Uosobieniem tego była postać, zmarłego w 2011 r., Vaclava Havla czy przyjęcie w 1990 r. przez Republikę Czechosłowacką, a później recypowanie w 1993 r. przez Republikę Czeską, orderu Tomasza Masaryka, nadawanego za zasługi w „rozwoju demokracji i praw człowieka" ${ }^{\prime 4}$.

Innym przykładem na współczesne odrodzenie myśli politycznej Masaryka jest duże zainteresowanie jego filozofią przez europejskich, ale nie tylko, naukowców, badaczy ustroju demokratycznego oraz roli państwa w tym reżimie.

Książka profesora Marka Bankowicza bez wątpienia jest pozycją, która nie tylko wypełniła lukę w światowym pisarstwie naukowym dotyczącym analizy myśli politycznej Tomasza Garrigue Masaryka, ale i opracowaniem, które swoją treścią i przyjemnym stylem pisania przybliża tę postać. Jest też komparatystyczną pracą naukową, wspierającą się nie tylko na pismach T.G.M., ale i na wielojęzycznych opracowaniach autorów naukowych, któ-

44 Zob. Stanovy, www.hrad.cz/cs/ceska-republika/statni-vyznamenani/ceska-a-slovenskafederativni-republika/rad-t.-g.-masaryka/stanovy [dostęp: 10.01.2017]. 
ings of the scholars who, despite cultural differences and historical experiences, see in Masaryk's democracy something more than a utopian dream. rzy - pomimo różnic kulturowych, doświadczeń historycznych - widzą w „demokracji” Masaryka coś więcej jak tylko utopijne marzenie.

\section{Marek Bankowicz, Demokracja według T.G. Masaryka, Kraków 2015, pp. 170.}

\section{Bibliography / Bibliografia}

Bankowicz M., Demokraci i dyktatorzy: przywódcy polityczni wspótczesnego świata, Kraków 1993. Bankowicz M., Demokracja według T.G. Masaryka, Kraków 2015.

Bankowicz M., Demokracja, zasady, procedury instytucje, Kraków 2006.

Bankowicz M., Kulisy totalitaryzmu: polityczna teoria dyktatury proletariatu, Kraków 1995.

Bankowicz M., System władzy państwowej Czechosłowacji i Czech. Studium instytucjonalno-polityczne, Kraków 1998.

Bankowicz M., Tomasz G. Masaryk - apostoł demokracji, “Tygodnik Powszechny” 29 IX 1991, No. 39.

Bankowicz M., Zamach stanu: studium teoretyczne, Kraków 2003.

Bankowicz M., Zlikwidowane państwo; ze studiów nad polityką Czechosłowacji, Kraków 2003.

Batowski H., Zdrada monachijska, Poznań, 1973.

Čapek K., Rozmowy z T.G. Masarykiem, trans. by P. Godlewski, Warszawa 2014.

Čapek K., Talks with T.G. Masaryk, New York 1953.

Gruchała J., Tomasz G. Masaryk, Wrocław 1996.

Hajek J.H., T.G. Masaryk, Revisited. A Critical Assessment, New York 1983.

Kaczorowski A., Przestrogi Masaryka, [in:] Rozmowy z Tomaszem Garriguem Masarykiem, Wrocław 2015.

Kilias J., Naród a idea narodowa. Nacjonalizm T.G. Masaryka, Warszawa 1998.

Łuszczyński A., Myśl polityczno-prawna Tomasza G. Masaryka jako rodzaj mitu państwowotwórczego, Rzeszów 2013.

Masaryk T.G., O Bolszewiźmie, trans. by A. Czerny, Warszawa 1922.

Masaryk T.G., Rewolucja światowa, trans. and edit. by W.M. Kozłowski, n.d.

Masaryk T.G., Rewolucja światowa, Warszawa-Poznań-Kraków-Lwów-Stanisławów, n.d.

Masaryk T.G., Słowianie po wojnie, trans. by i wstęp O. Ortwin, Lwów 1924.

Schmidt-Hartmann E., Thomas G. Masaryk's Realism. Origins of a Czech Political Concept, München 1984.

Stanovy, www.hrad.cz/cs/ceska-republika/statni-vyznamenani/ceska-a-slovenska-federativnirepublika/rad-t.-g.-masaryka/stanovy [access on: 10.01.2017].

Szporluk R., The Political Thought of Thomas G. Masaryk, New York 1981.

Article submitted: 12.01.2017; article accepted: 27.02.2017 